\title{
DO INDONESIAN GOVERNMENT DEPLOY RELIABLE AMMUNITION FOR COVID-19 MASS TEST? A COMPARISON OF REAL-TIME PCR KITS
}

\author{
NELLY MARISSA ${ }^{1 *}$, SALMIATY ${ }^{1}$, SARI HANUM ${ }^{1}$, EVAN FEBRIANSYAH ${ }^{1}$, NUR RAMADHAN ${ }^{1}$, YULIDAR $^{1}$, \\ ZAIN HADIFAH ${ }^{1}$, AGUNG PRANATA ${ }^{2}$
}

${ }^{1}$ Balai Penelitian dan Pengembangan Kesehatan Aceh, Aceh, Indonesia. ${ }^{2}$ Department of Parasitology, School of Medicine, Universitas Syiah Kuala, Aceh, Indonesia. Email: nellymarissa@gmail.com

Received: 27 January 2021, Revised and Accepted: 18 March 2021

\section{ABSTRACT}

Objective: This study aimed to compare the level of reliability of three commercial real-time PCR kits in determining clinical samples.

Methods: A total of 40 swabs samples which were previously tested positive, were re-test using the BioCov-19 RT-PCR kit, Sansure coronavirus disease 19 (COVID-19) nucleic acid diagnostic kit, and Kogen PowerCheck with Thermocycler (Roche). The amplification procedure is carried out based on the manual for each kit.

Results: Sansure COVID-19 nucleic acid diagnostic was able to detect 40 samples with positive severe acute respiratory syndrome coronavirus 2 (SARS-COV-2) results detected in both genes, while the PowerChek ${ }^{\text {tw }} 2019$-nCoV real-time PCR kit able to detect 35 samples showed that SARS-COV-II was detected in both genes, and the BioCoV-19 RT-PCR Kit brand kit able to detect 34 samples showed positive SARS-COV-2 results in both genes.

Conclusion: The three commercial kits show great ability detection, so that they can be used to detect the presence of SARS-COV-II in clinical samples, and also in mass screening.

Keywords: SARS-CoV-2, COVID 19, PCR.

(C) 2021 The Authors. Published by Innovare Academic Sciences Pvt Ltd. This is an open access article under the CC BY license (http://creativecommons.org/ licenses/by/4.0/) DOI: http://dx.doi.org/10.22159/ajpcr.2021v14i5.40078. Journal homepage: https://innovareacademics.in/journals/index.php/ajpcr

\section{INTRODUCTION}

Since its first documented case, coronavirus disease 19 (COVID-19) has a massive spread throughout the continent and set its mark on the fourth populous country, Indonesia. The cause of this acute respiratory problem is the severe acute respiratory syndrome coronavirus 2 (SARSCoV-2). This virus is an RNA virus, $89 \%$ of its nucleotides resemble SARS-like-CoVZXC21 and there are $82 \%$ of nucleotides similar to human SARS-CoV [1,2].

The World Health Organization reckons the Polymerase Chain reaction (PCR) is a diagnostic tool used to detect the presence of SARS-CoV-2. Various genes are targeted to detect the presence of this virus, including RNA-dependent RNA polymerase (RdRP), S which codes for surface structural proteins, $\mathrm{N}$ which encodes for nucleocapsid proteins, $\mathrm{E}$ which encodes for envelope protein, and orf1ab which encodes for orf1ab polyprotein [3].

Differences in the target genes used can result in differences in the sensitivity and specificity levels of these kits. Research conducted by Mollaei concluded that the use of the RdRP, N, and ORF1ab genes have a higher level of sensitivity and specificity of S and E [4]. Various commercially available kits have been widely used to detect the presence of these viruses, targeting two or three genes. However, very little data are available on the comparison of the sensitivity of each of these commercial kits. Therefore, in this study, we wanted to compare the ability of each target gene from three commercial PCR kits used to detect the presence of SARS-CoV-2.

\section{METHODS}

\section{Kit selection}

We select three different RT-PCR Kits distributed by the Indonesian Government since May 2020. There are the BioCov-19 RT PCR kit,
Sansure COVID-19 nucleic acid diagnostic kit, and Kogen PowerCheck. All three had approved by the Indonesian Ministry of Health.

\section{Sample collection}

The data were obtained from routine SARS-CoV-2 detection samples in the Aceh Health research and Development Center Laboratory (based on the Decree of the Minister of Health, Republic of Indonesia No.HK.01.07/MENKES/214/2020). The sample used is in the form of stored biological material, the samples in this study were nasopharyngeal and oropharyngeal. A total of 40 samples previously tested positive were included in further analysis. This research has already approved by Health studies, Politeknik Kesehatan Kementrian Kesehatan Aceh, number LB.02.03/6.7/02.09/2020.

\section{RNA extraction}

RNA extraction was carried out using the Zeesan ${ }^{\circledR}$ viral RNA extraction kit. $500 \mu \mathrm{l}$ of the sample, $1000 \mu \mathrm{l}$ of RNA lysis buffer, and $5 \mu \mathrm{l}$ of PolyA solution were added to the tube. Then, as much as $50 \mu \mathrm{l}$ of magnetic particle suspension was added to the tube and incubated for $5 \mathrm{~min}$. The tube is placed on the magnetic stand for $60 \mathrm{~s}$, and then the liquid is discarded. A total of $800 \mu \mathrm{l}$ of wash buffer R1 was added, and then transferred to a new tube. The tube is put back on the magnetic stand for $60 \mathrm{~s}$, and then the liquid is discarded. A total of $1000 \mu \mathrm{l}$ of wash buffer R2 was added to the tube, and then the liquid was transferred to the new tube and placed on the magnetic stand for $30 \mathrm{~s}$. Furthermore, the liquid is discarded. A total of $1000 \mu \mathrm{l}$ of wash buffer R3 was inserted into the tube and placed on the magnetic stand for $20 \mathrm{~s}$, and then the liquid was discarded. Then, as much as $60 \mu \mathrm{l}$ of RNA elution buffer was put into the tube and vortexed for $5 \mathrm{~min}$. The tube is placed on the magnetic stand for $30 \mathrm{~s}$. Then, the fluid can be transferred to a new tube.

The RNA template quantification with Nanodrop A simple RNA quantification through RNA spectrophotometer (MN913A MaestroNano Pro, MaestroGen, Taiwan) was used to determine 
the total RNA templates in each sample. The complete checked concentration of the template RNA is shown in Table 1. Although the concentration did not correlate exclusively to targeted SARS-CoV-2 RNA, this quantification excluded the possibility of running the incorrect samples. The mean concentration of the RNA template was $34.2 \mathrm{ng} / \mu \mathrm{l}$, ranged from $4.2 \mathrm{ng} / \mu \mathrm{l}$ to $128.6 \mathrm{ng} / \mu \mathrm{l}$

\section{PCR reaction and analysis}

PCR reaction was mixed using the BioCov-19 RT PCR kit, Sansure Covid-19 nucleic acid diagnostic kit, and Kogen Powercheck. The work procedure is carried out based on the instructions for each kit. PCR examination was performed using a Light cycler 480 (Roche Molecular Systems, Inc., Germany).

The BioCov-19 RT PCR Kit targets the N2 and RdRP genes. For reactions using the BioCov-19 RT PCR kit, $10 \mu \mathrm{l}$ of the one-step mix was added, followed by the addition of the reverse transcriptase enzyme as much as $0.2 \mu \mathrm{l}$. Then, $0.4 \mu \mathrm{l}$ of RNAse inhibitor was added to the reaction. It was ended with the addition of a reaction mix containing $1.5 \mu \mathrm{l}$ of primer and probe each and $2.9 \mu \mathrm{l}$ of $\mathrm{DEPC}-\mathrm{H}_{2} 0$. The sample required for each of these reactions is $5 \mu \mathrm{l}$. The PCR reaction was carried out at $45^{\circ} \mathrm{C}$ for $15 \mathrm{~min}$ for the reverse transcription step, followed by the denaturation stage at $95^{\circ} \mathrm{C}$ for $2 \mathrm{~min}$. Then, 45 cycles of DNA duplication were carried out at $95^{\circ} \mathrm{C}$ for $3 \mathrm{~s}$ and $55^{\circ} \mathrm{C}$ for $30 \mathrm{~s}$.

Sansure COVID-19 nucleic acid diagnostic kit detects the N and ORF$1 \mathrm{ab}$ genes. Each reaction requires $26 \mu \mathrm{l}$ of $2019 \mathrm{nCoV}$ PCR mix and $4 \mu \mathrm{l}$ of $2019 \mathrm{nCoV}$ enzyme mix. The sample size required for this reaction is $20 \mu \mathrm{l}$. The PCR reaction was carried out at $50^{\circ} \mathrm{C}$ for $30 \mathrm{~min}$ for reverse transcription, followed by cDNA predenaturation at $95^{\circ} \mathrm{C}$ for $1 \mathrm{~min}$, denaturation at $95^{\circ} \mathrm{C}$ for $15 \mathrm{~s}$, and annealing at $60^{\circ} \mathrm{C}$ for $30 \mathrm{~s}$. The cycle was repeated 45 times.

The 2019-nCoV Real-time PCR PowerChek ${ }^{\mathrm{TM}}$ Kit detects E and RdRP genes. The reaction was done by adding $11 \mu \mathrm{l}$ of premix RT-PCR and $4 \mu \mathrm{l}$ of primer and probe. The sample used was $5 \mu \mathrm{l}$. The PCR reaction was carried out at $50^{\circ} \mathrm{C}$ for $30 \mathrm{~min}$, followed by $95^{\circ} \mathrm{C}$ for $10 \mathrm{~min}$ and then at a temperature of $95^{\circ} \mathrm{C}$ for $15 \mathrm{~s}$ and $60^{\circ} \mathrm{C}$ for $1 \mathrm{~min}$. This cycle was repeated 40 times.

\section{RESULT}

Based on the results of the examination using Nanodrop, the lowest RNA concentration is $4.2 \mathrm{ng} / \mu \mathrm{l}$, and the higher RNA concentration is $128.6 \mathrm{ng} / \mu \mathrm{l}$ (Table 1$)$

Based on the SARS-COV-II detection results using three RT-PCR kits, it was found that with the use of the PowerChek ${ }^{\text {tw }}$ 2019-nCoV real-time PCR kit, 35 samples showed that SARS-CoV-2 was detected in both genes. Using the BioCoV-19 RT-PCR Kit brand kit 34 samples showed positive SARS-CoV-2 results in both genes. Using Sansure COVID-19 nucleic acid diagnostic, there were 40 samples with positive SARSCoV-2 results detected in both genes (Table 2)

\section{DISCUSSION}

This study compared the detection results of SARS-CoV-2 uses three commercial kits distributed by the Government of the National Disaster Management Agency (BNPB), National Institute of Health Research and Development, Indonesian Ministry of Health (Badan Litbangkes Kemenkes RI). All three kits work by detecting the presence of SARS-CoV-2 uses two detection genes. The genes used were E, N2, RdRP, and ORF1ab. All of the target genes are in the conserved region.

We found that the PowerChek ${ }^{\mathrm{TM}}$ 2019-nCoV real-time PCR kit from Kogene Biotech successfully detected the presence of SARS-CoV-2 in 35 samples. However, two samples were only successfully detected using one gene, namely, RdRP. Meanwhile, there is only one sample detected in the $\mathrm{E}$ gene. Detection with the $\mathrm{E}$ gene using this kit, there will be
Table 1: RNA concentration analysis of positive COVID samples 19 nanodrop method (sample $1 \mu \mathrm{l}$ )

\begin{tabular}{llll}
\hline S. No. & $(\mathbf{n g} / \boldsymbol{\mu l})$ & No & $\boldsymbol{\chi}(\mathbf{n g} / \mathbf{u l})$ \\
\hline 1 & NA & 21 & 19.7 \\
2 & 42.1 & 22 & 36.3 \\
3 & 28.2 & 23 & NA \\
4 & 72.3 & 24 & 34.2 \\
5 & 13.6 & 25 & 37.9 \\
6 & 8.8 & 26 & NA \\
7 & 4.2 & 27 & 39.2 \\
8 & 9.6 & 28 & NA \\
9 & 27.2 & 29 & 43.1 \\
10 & 18.4 & 30 & NA \\
11 & 54.1 & 31 & 31 \\
12 & 5.4 & 32 & NA \\
13 & 43.2 & 33 & 23 \\
14 & 17.2 & 34 & 128.6 \\
15 & NA & 35 & 19.3 \\
16 & 51.3 & 36 & 12.7 \\
17 & 32.6 & 37 & 49.6 \\
18 & 22.7 & 38 & 45.8 \\
19 & 81 & 39 & 25.8 \\
20 & 21.5 & 40 & 28.6 \\
\hline
\end{tabular}

NA: Not available

Table 2: SARS-CoV-2 detection test results

\begin{tabular}{llll}
\hline & $\begin{array}{l}\text { PowerChek } \\
\text { 2019-nCoV real } \\
\text { time polymerase } \\
\text { chain reaction kit }\end{array}$ & $\begin{array}{l}\text { BioCoV-19 RT - } \\
\text { polymerase chain } \\
\text { reaction Kit }\end{array}$ & $\begin{array}{l}\text { Sansure } \\
\text { COVID-19 } \\
\text { nucleic acid } \\
\text { diagnostic }\end{array}$ \\
\hline $\begin{array}{l}\text { Detected in } \\
\text { both genes }\end{array}$ & 35 & 34 & 40 \\
$\begin{array}{l}\text { Detected in } \\
\text { one of the }\end{array}$ & 3 & 6 & - \\
$\begin{array}{l}\text { genes } \\
\text { Not detected }\end{array}$ & 2 & & - \\
\hline
\end{tabular}

cross-reactions with other beta coronaviruses. Moreover, two samples were not detected SARS-CoV-2 with both genes.

Meanwhile, using the BioCoV-19 RT-PCR Kit from Biofarma successfully detected the presence of SARS-CoV-2 in both genes in 34 samples. Six other samples were only detected in one gene, the N2 gene. In general, it can be concluded that this kit was successful in detecting SARS-CoV-2 in all samples. Using the Sansure COVID-19 nucleic acid diagnostic kit, all samples were successfully detected in the presence of SARS-CoV-2 using the $\mathrm{N}$ and ORF1b genes.

In general, these three commercial kits can be used to detect the presence of SARS-CoV-2, although there is still cross-reaction with other beta coronaviruses if only detected with the $\mathrm{E}$ gene in the PowerChek $^{\mathrm{TM}}$ 2019-nCoV real-time PCR kit. Based on research conducted by Corman, it was concluded that the detection of SARS$\mathrm{CoV}-2$ was best done by targeting the $\mathrm{E}$ and RdRP genes compared to the $\mathrm{N}$ [5]. Igloi stated that the sensitivity level of the PowerChek ${ }^{\mathrm{TM}}$ 2019-nCoV real-time PCR kit and Sansure COVID-19 nucleic acid diagnostic kit> 90\% [6]. Kasteren, who compared seven commercial kits, including the PowerChek ${ }^{\mathrm{TM}}$ 2019-nCov real time PCR and Sansure COVID-19 nucleic acid diagnostic, also concluded that the results were very satisfying [7].

\section{CONCLUSION}

The three commercial kits have a high level of sensitivity so that they can be used to detect the presence of SARS-CoV-2. The detection ability of each kit is still different. Sansure COVID-19 nucleic acid diagnostic kit has higher capabilities than the other two kits. 


\section{ACKNOWLEDGMENT}

We would like to thank to the head of Balai Litbangkes Aceh, Mr. Dr. Fahmi Ichwansyah, S. Kp, MPH; Laboratory of Aceh Health Research and Development Center, and Laboratory of Infectious Diseases, Faculty of Medicine, Syiah Kuala University for supporting this research

\section{AUTHORS CONTRIBUTION}

The author's contribution was as follows: Nelly Marissa wrote the manuscript, Salmiaty, Sari hanum, Evan Febriansyah and Agung Pranata measured RNA concentration and PCR, Nur Ramadhan, Yulidar and Zain Hadifah data analysis and correction.

\section{CONFLICTS OF INTEREST}

The authors declare that they have no conflicts of interest.

\section{AUTHORS FUNDING}

The authors declare that there is no source of funding.

\section{REFERENCES}

1. Chan JF, Kok KH, Zhu Z, Chu H, To KK, Yuan S, et al. Genomic characterization of the 2019 novel human-pathogenic coronavirus isolated from a patient with atypical pneumonia after visiting Wuhan. Emerg Microbes Infect 2020;9:221-36.

2. Lu R, Zhao X, Li J, Niu P, Yang B, Wu H, et al. Genomic characterisation and epidemiology of 2019 novel coronavirus: Implications for virus origins and receptor binding. Lancet 2020;395:565-74.

3. Khailany RA, Safdar M, Ozaslan M. Genomic characterization of a novel SARS-CoV-2. Gene Rep 2020;19:100682.

4. Mollaei HR, Afshar AA, Kalantar-Neyestanaki D, Fazlalipour M, Aflatoonian B. Comparison five primer sets from different genome region of covid-1for detection of virus infection by conventional rt-pcr. Iran J Microbiol 2020;12:185-93.

5. Corman VM, Landt O, Kaiser M, Molenkamp R, Meijer A, Chu DK, et al. Detection of 2019 novel coronavirus $(2019-\mathrm{nCoV})$ by real-time RT-PCR. Euro Surveill 2020;25:2000045.

6. Iglói Z, leven M, Abou-Nouar ZA, Weller B, Matheeussen V, Coppens J, et al. Comparison of commercial realtime reverse transcription PCR assays for the detection of SARS-CoV-2. J Clin Virol 2020;129:104510.

7. van Kasteren PB, van der Veer B, van den Brink S, Wijsman L, De Jonge J, van den Brandt A, et al. Comparison of seven commercial RTPCR diagnostic kits for COVID-19. J Clin Virol 2020;128:104412. 